\title{
Defect Type Code
}

National Cancer Institute

\section{Source}

National Cancer Institute. Defect Type Code. NCI Thesaurus. Code C93547.

A coded value specifying the kind of reported problem with the product. 